\title{
Komunikasi Interpersonal sebagai Strategi Dakwah Rasulullah (Perspektif Psikologi)
}

\author{
Halimatus Sakdiah
}

Fakultas Dakwah dan Komunikasi IAIN Antasari

\begin{abstract}
This paper describes about the psychological perspective on interpersonal communication as one of the strategies the Prophet in preaching. Interpersonal communication is communication btween two or more people in order to achieve the desired objectives. In the context of the history of dakwah of Rasullullah SAW, interpersonal communication has been used as a dakwah strategy of the first when he was newly appointed as an apostle and called on the Islamic religion commanded. Interpersonal communication is done by Rasullullah in psychology perspective is a communication in psychological level. Psychologically interpersonal communication will go well if the two sides are communicating it had known each other, giving each other the attention, support, openness and trust. So the use of appropriate interpersonal communication and effective will affect the success of dakwah Islamiyah.
\end{abstract}

Keywords: interpersonal communication, the call of the Prophet, psychology

Tulisan ini memaparkan tentang perspektif psikologi tentang komunikasi interpersonal sebagai salah satu strategi Rasulullah dalam berdakwah. Komunikasi interpersonal merupakan komunikasi yang dilakukan dua orang atau lebih dalam rangka mencapai tujuan yang diinginkan. Dalam konteks sejarah dakwah Rasullullah SAW, komunikasi interpersonal telah digunakan sebagai strategi dakwah pertama pada saat beliau baru diangkat menjadi rasul dan diperintahkan menyerukan agama Islam. Komunikasi interpersonal yang dilakukan Rasullullah dalam tinjauan psikologi merupakan komunikasi tingkat psikologis. Secara psikologis komunikasi interpersonal akan berjalan dengan baik jika kedua belah pihak yang berkomunikasi itu telah mengenal satu sama lain, saling memberikan perhatian, dukungan, keterbukaan dan kepercayaan. Sehingga penggunaan komunikasi interpersonal yang tepat dan efektif akan mempengaruhi keberhasilan dakwah Islamiyah.

Kata kunci: komunikasi interpersonal, dakwah Rasulullah, psikologi

Dakwah merupakan proses penyampaikan pesan kepada mad'u untuk mencapai tujuan yang diinginkan. Dakwah juga mengandung arti kegiatan mengajak orang lain kepada jalan kebenaran. Dari kegiatan mengajak orang lain menunjukkan bahwa pada dasarnya dakwah merupakan kegiatan interaksi sosial. Dalam proses interaksi itu terdapat tindakan saling mempengaruhi antara da'i dan mad'u. Keduanya terjadi proses pengaruh-mempengaruhi, merubah atau memperbaiki perilaku antara da'i dan mad'u atau sebaliknya.

Dalam proses mempengaruhi tersebut hal yang diperlukan adalah kemampuan berkomunikasi. Dalam hal ini komunikasi dapat diartikan sebagai proses

Email penulis: halima_sakdia@ymail.com

Alhadharah Jurnal Ilmu Dakwah Vol. 15 No. 30, Juli-Desember 2016, 39-51 
penyampaian informasi dan pemahaman umum dari seseorang kepada orang lain. Komunikasi tersebut menurut Effendy (2011: 8) memiliki tujuan yaitu: 1) perubahan sikap (attitude change), 2) perubahan pendapat (opinion change), 3) perubahan perilaku (behavior change) dan 4) perubahan sosial (social change). Sehingga dapat dikatakan bahwa tujuan komunikasi adalah untuk merubah sikap dan perilaku komunikan sesuai dengan tujuan yang diinginkan komunikator.

Komunikasi ada berbagai macam bentuk, diantaranya adalah komunikasi intra personal, komunikasi interpersonal, komunikasi kelompok, komunikasi massa dan lain-lain. Komunikasi yang akan diuraikan adalah komunikasi interpersonal. Istilah komunikasi interpersonal lebih dikenal dengan sebutan komunikasi antar pribadi. Komunikasi antar pribadi adalah proses komunikasi yang berlangsung antara dua orang atau lebih secara tatap muka (Cangara, 2012: 36).

Komunikasi interpersonal ini dapat digunakan para dai sebagai strategi dakwah. Kemampuan berkomunikasi interpersonal sangat mendukung kegiatan dakwah. Sejarah dakwah yang dilakukan Rasulullah dapat menjadi rujukan bagi para da'i dalam melaksanakan dakwah. Pada saat Rasulullah menerima wahyu pertama, komunikasi interpersonal face to face menjadi langkah pertama yang dilakukan oleh Rasulullah terutama pada tiga tahun pertama ketika dakwah dilaksanakan secara sembunyi-sembunyi di kota Mekkah

Oleh karena itu, tulisan ini mencoba mengupas komunikasi interpersonal sebagai salah satu strategi dakwah, komunikasi interpersonal dalam konteks dakwah Rasulullah dan juga perspektif psikologi tentang komunikasi interpersonal dalam konteks dakwah Rasulullah SAW.

\section{Konsep Komunikasi Interpersonal}

Komunikasi antar pribadi (interpersonal communication) adalah komunikasi antara orang-orang secara tatap muka, yang memungkinkan setiap pesertanya menangkap reaksi orang lain secara langsung, baik secara verbal ataupun nonverbal (Mulyana, 2013: 81). Komunikasi interpersonal yang berlangsung antara dua orang dikenal dengan istilah diadik ( $d y a d$ ). Diadik merupakan konteks umum komunikasi interpersonal, karena setiap pasangan dalam interaksi fokus memperhatikan semata-mata pada lawan bicaranya (Solomon D. \& Theiss J. 2013: 6).

Mark L, Knapp dan John Augustine Daly (2002: 3) menyatakan bahwa komunikasi interpersonal dapat diartikan sebagai kemampuan untuk berhubungan dengan orang-orang secara tulisan maupun komunikasi verbal. Tipe komunikasi ini dapat terjadi dalam setting perorangan dan dalam kelompok. Ini juga berarti mampu menangani orang yang berbeda dalam situasi berbeda, dan membuat orang merasa nyaman. Gerak isyarat seperti kontak mata, gerakan tubuh, dan gerakan tangan juga merupakan bagian komunikasi interpersonal. Fungsi paling umum dari komunikasi interpersonal adalah mendengarkan, berbicara dan resolusi konflik. Tipe komunikasi interpersonal bermacam-macam dari verbal sampai nonverbal, dan dari situasi ke situasi. Komunikasi interpersonal melibatkan komunikasi tatap muka untuk mencapai maksud tertentu dan secara tepat.

Menurut sifatnya, komunikasi interpersonal dapat dibedakan atas dua macam, yakni komunikasi diadik (dyadic communication) dan komunikasi kelompok kecil 
(small group communication). Komunikasi diadik adalah proses komunikasi yang berlangsung antara dua orang dalam situasi tatap muka. Komunikasi kelompok kecil adalah proses komunikasi yang berlangsung antara tiga orang atau lebih secara tatap muka, di mana anggota-anggotanya saling berinteraksi satu sama lainnya (Cangara, 2012: 36)

Lebih lanjut Cangara (2012: 37) menjelaskan bahwa komunikasi kelompok kecil oleh banyak kalangan dinilai sebagai tipe komunikasi antarpribadi karena: Pertama, anggota-anggotanya terlibat dalam suatu proses komunikasi yang berlangsung secara tatap muka. Kedua, pembicaraan berlangsung secara terpotong-potong di mana semua peserta bisa berbicara dalam kedudukan yang sama dengan kata lain tidak ada pembicara tunggal yang mendominasi situasi. Ketiga, sumber dan penerima sulit diidentifikasi. Dalam situasi seperti ini, semua anggota bisa berperan sebagai sumber dan juga sebagai penerima.

Komunikasi interpersonal fokus menekankan pada proses interaksi seseorang lebih dari interaksi verbal, menekankan tingkah laku dan keterampilan untuk komunikasi interpersonal. Komunikasi interpersonal termasuk dimensi afektif dan kognitif diambil dari ilmu yang berhubungan dengan tingkah laku dan ilmu lainnya termasuk humanistik. Komunikasi interpersonal memperhatikan tentang pesan dan tanggapan verbal dan nonverbal manusia, dan menunjukkan perhatian pada penyelidikan objektif dari pengalaman komunikasi antar individu (Ramaraju: 2012: 70)

Komunikasi interpersonal dapat menjadi alat yang berguna untuk menawarkan kritik konstruktif, mengelola konflik, memberikan dukungan, atau berbagi momen lucu. Keterampilan komunikasi interpersonal juga penting dalam berbagai situasi lain, seperti ketika kita berbicara dengan tetangga baru, mengkoordinasikan jadwal dengan teman, atau bernegosiasi dengan atasan. Anda dapat menggunakan komunikasi interpersonal untuk membangun hubungan yang sukses di rumah, di sekolah, di tempat kerja, dan di depan umum. karena komunikasi interpersonal selalu menjadi bagian dari hidup kita (Solomon D. \& Theiss J. 2013: 4)

Komunikasi interpersonal lebih mengacu khusus untuk komunikasi yang terjadi antara orang-orang dan menciptakan ikatan pribadi antara mereka. Komunikasi interpersonal menciptakan hubungan antara orang, sehingga tindakan satu orang mempengaruhi dan mencerminkan tindakan orang lain. Komunikasi interpersonal melibatkan memperhatikan karakteristik dan keadaan yang membuat peserta individu yang unik (Solomon D. \& Theiss J. 2013:5). Pengaruh tujuan interpersonal yang diinginkan berhasil dicapai hanya jika kita meyakinkan orang lain untuk bekerja sama dengan kita. Apakah kita mencapai pengaruh tujuan interpersonal tergantung pada kemampuan untuk berkomunikasi dalam mengubah pikiran atau perilaku orang lain.(Solomon, D \& Theiss, J. 2013: 323).

Dari uraian di atas dapat disimpulkan bahwa komunikasi interpersonal merupakan proses penyampaian pesan yang dilakukan dua orang atau lebih (kelompok kecil), dan terjadi umpan balik, melalui media yang dilakukan secara langsung atau tidak langsung, untuk mengubah, memperbaiki dan mempengaruhi orang lain dalam rangka mencapai tujuan tertentu.

\section{Strategi Dakwah}

Dakwah secara bahasa berasal dari kata da'a, yad'u, da'watan yang berarti ajakan, seruan, undangan dan panggilan. Pada intinya arti dakwah adalah segala aktivitas dan kegiatan mengajak orang untuk berubah dari suatu situasi yang 
mengandung nilai bukan islami kepada nilai yang islami (Kusnawan, dkk., 2009: 15-16). Komunikasi memiliki peran penting dalam usaha mengajak orang lain untuk mengikuti ajakan seseorang, termasuk dalam hal berdakwah.

Enjang dan Aliyudin (2009: 2-5) mengemukakan bahwa persepsi dan pemahaman masyarakat tentang dakwah pengalami sedikit perubahan. Pada masa lalu dan mungkin sekarang masih ada, mengartikan dakwah sama dengan ceramah (tabligh atau khithabah) yaitu proses menyampaikan ajaran Islam secara lisan yang dilakukan oleh penceramah di atas mimbar atau dalam pengajian majelis taklim. Padahal pengertian dakwah lebih luas dari itu, dakwah adalah mengajak manusia kepada jalan Allah (sistem Islam) secara menyeluruh; baik dengan lisan, tulisan, maupun dengan perbuatan sebagai ikhtiar (upaya) mewujudkan nilai-nilai ajaran Islam dalam realitas kehidupan pribadi, keluarga dan masyarakat dalam semua segi kehidupan secara menyeluruh sehingga terwujud khairul ummah (masyarakat madani).

Menyerukan kebenaran dan mencegah kemungkaran adalah tugas hidup setiap manusia. Dengan bahasa lain setiap muslim berkewajiban untuk berdakwah. Perintah ini ditulis dalam al-Qur'an surat Ali Imran ayat 110, yang artinya: "Kamu adalah umat yang terbaik yang dilahirkan untuk manusia, menyuruh kepada yang ma'ruf, dan mencegah dari yang munkar, dan beriman kepada Allah".

Dakwah merupakan bagian dari tugas suci (ibadah) umat Islam. Sebagai juru dakwah atau da'i tentu saja ingin mencapai kesuksesan dalam mencapai tugas dakwah. Salah satu bentuk keberhasilan dalam dakwah adalah berubahnya sikap kejiwaan seseorang. Untuk dapat merubah sikap kejiwaan seorang sebagai indikator tercapainya kesuksesan dalam berdakwah memerlukan strategi yang tepat.

Strategi dakwah adalah perencanaan yang berisi rangkaian kegiatan yang didesain untuk mencapai tujuan dakwah tertentu. Ada dua hal yang perlu diperhatikan dalam hal ini, yaitu:

1. Strategi merupakan rencana tindakan (rangkaian kegiatan dakwah) termasuk penggunaan metode dan pemanfaatan berbagai ssumber daya atau kekautan.

Dengan demikian, strategi merupakan proses penyusunan rencana kerja, belum sampai pada tindakan.

2. Strategi disusun untuk mencpaai tujuan tertentu. Artinya, arah dari semua keputusan penyusunan strategi adalah pencapaian tujuan. Oleh sebab itu, sebelum menentukan strategi, perlu dirumuskan rujuan yang jelas serta dapat diukur keberhasilannya (Wina Sanjaya, 2007, dalam Moh. Ali Aziz, 2009: 350).

Dalam kegiatan komunikasi, (Effendi, 1993 dalam Moh. Ali Aziz, 2009: 351) mengartikan strategi sebagai perencanaan (planning) dan manajemen (manajement) untuk mencapai suatu tujuan. Ia tidak hanya berfungsi sebagai peta jalan yang harus ditempuh, tetapi juga berisi taktik operasionalnya. Ia harus didukung teori karena teori merupakan pengetahuan berdasarkan pengalaman yang ssudah diuji kebenarannya. Untuk strategi komunikasi tersebut, segala sesuatunya harus memperhatikan komponen komunikasi dalam teori What in Which Channel to Whom wih What effect (komunikator, pesan, media, komunikan, dan efek).

Al-Bayanuni (1993 dalam Aziz, 2009: 351) mendefinisikan strategi dakwah (manahij al-da'wah) sebagai berikut: Ketentuan-ketentuan dakwah dan rencanarencana yang dirumuskan untuk kegiatan dakwah. Selanjutnya Al-Bayununi membagi strategi dakwah dalam tiga bentuk, yaitu:

1. Strategi sentimental (al-manhaj al-'athifi)

2. Strategi rasional (al-manhaj al-'aqli) 
3. Strategi indriawi (al-manhaj al-hissi)

Strategi sentimental adalah dakwah yang menfokuskan aspek hati dan menggerakkan perasaan dan batin mitra dakwah. Memberi mitra dakwah nasehat yang mengesankan, memanggil dengan kelembutan, atau memberikan pelayanan yang memuaskan merupakan beberapa metode yang dikembangkan dari strategi ini. Metode-metode ini sesuai untuk mitra dakwah yang terpinggirkan (marginal) dan dianggap lemah, seperti kaum perempuan, anak-anak, orang yang masih awam, para mualaf (imannya lemah), orang-orang miskin, anak-anak yatim, dan sebagainya. Strategi sentimental ini diterapkan oleh Nabi SAW saat menghadapi kaum musyrik Mekkah. Tidak sedikit ayat-ayat Makkiyah (ayat yang diturunkan ketika Nabi di Mekkah atau sebelum Nabi SAW hijrah ke Madinah) yang menekankan aspek kemanusiaan (humanism), semacam kebersamaan, perhatian kepada fakir miskin, kasih sayang kepada anak yatim, dan sebagainya. Ternyata, para pengikut Nabi SAW pada masa awal umumnya berasal dari golongan kaum lemah. Dengan strategi ini, kaum lemah merasa dihargai dan kaum mulia merasa di hormati.

Strategi rasional adalah dakwah dengan beberapa metode yang memfokuskan pada aspek akal pikiran. Strategi ini mendorong mitra dakwah untuk berpikir, merenungkkan, dan mengambil pelajaran. Penggunaan hukum logika, disskusi, atau penampilan contoh dan bukti sejarah merupakan beberapa metode dari strategi rasional.

Al-qur'an mendorong penggunaan strategi rasional dengan beberapa terminology antara lain: tafakkur, tadzakkur, nazhar, taammul, i'tibar, tadabbur, dan istibshar. Tafakkur adalah menggunakan pemikiran untuk mencapainya dan memikirkannya; tadzakkur merupakan menghadirkan ilmu yang harus dipelihara setelah dilupakan; nazhar ialah mengarahkan hati untuk berkonsentrasi pada objek yang sedang diperhatikan; taammul berarti mengulang-ulang pemikiran hingga menemukan kebenaran dalam hatinya; I'tibar bermakna perpindahan dari pengetahuan yang sedang dipikirkan menju pengetahuan yang lain; tadabbur adalah suatu usaha memikirkan akibat-akibat setiap masalah; istibshar ialah megungkap sesuatu atau menyingkapnya, serta memperlihatkannya kepada pandangan hati (Muhammad Yusuf al-Qardlawi, 1998: 63-64 dalam Aziz, 2009: 352-353).

Strategi indriawi juga dapat dinamakan dengan strategi eksperimen atau strategi ilmiah. Ia didefinisikan sebagai sistem dakwah atau kumpulan metode dakwah yang berorientasi pada pancaindera dan berpegang teguh pada hasil penelitian dan percobaan. Di antara metode yang dihimpun oleh strategi ini adalah praktrik keagamaan, keteladanan, dan pentas drama. Dahulu, Nabi SAW mempraktekkan Islam sebagai perwujudan strategi indriawi yang disaksikan oleh para sahabat. Para sahabat dapat menyaksikan mukjizat Nabi SAW, secara langsung, seperti terbelahnya rembulan, bahkan menyaksikan Malaikat jibril dalam bentuk manusia (Moh. Ali Aziz, 2009: 353).

Strategi dakwah dilaksanakan untuk mencapai tujuan dakwah. Tujuan dakwah dapat dibagi menjadi dua macam, yaitu tujuan umum dan tujuan khusus. Tujuan umum merupakan garis pokok yang menjadi arah semua kegiatan dakwah yaitu perubahan sikap dan perilaku mitra dakwah sesuai dengan ajaran Islam. Tujuan umum ini tidak bisa dicapai sekaligus karena mengubah sikap dan perilaku seseorang, bukan pekerjaan sederhana. Oleh karena itu perlu tahap-tahap pencapaian. Tujuan pada setiap tahap itulah yang disebut tujuan khusus. Tujuan utama itulah yang dijadikan dasar penyusunan strategi dakwah dengan 
memperhatikan masing-masing tujuan khususnya. Adapun strategi dakwah yang digunakan Rasulullah dapat dilihat dari konteks sejarah dakwah pada masa Rasullullah.

\section{Komunikasi Interpersonal dalam Konteks Dakwah Rasulullah}

Nabi Muhammad SAW sebelum diangkat menjadi nabi dan rasul, biasa berkhalwat dan bertafakkur/ berkontemplasi di Gua Hira, beberapa kilometer sebelah utara kota Makkah. Saat itu, 17 Ramadlan tahun 13 Sebelum Hijrah, bertepatan dengan 6 Agustus $610 \mathrm{M}$, ketika Muhammad sedang berkhalwat di Gua Hira, Jibril menyampaikan wahyu pertama, yaitu lima ayat dari Surat Al-'Alaq. Dengan turunnya wahyu pertama, berarti Muhammad telah dipilih Tuhan sebagai Nabi, yang pada saat itu beliau berusia 40 tahun. Wahyu pertama ini, belum mengandung perintah untuk menyeru manusia kepada suatu agama. Artinya, Muhammad telah diangkat menjadi nabi, tetapi belum menjadi rasul, sebab belum diberi kewajiban menyampaikan risalah (Badri Yatim, 2005: 7).

Setelah wahyu pertama turun, Jibril tidak muncul lagi untuk beberapa lama. Selanjutnya turun wahyu Q.S. Al-Muzzammil, 73; 1-9, dan Q.S. Al-Mudatsir, 74; 17. Kedua wahyu ini, menjadi simbol diangkatnya Nabi Muhammad menjadi Rasulullah (utusan Allah) yang dibebani kewajiban menyeru (memberi peringatan) bukan hanya kepada bangsa Arab saja, melainkan kepada seluruh manusia, agar mengikuti yang risalah yang dibawanya. (Badri Yatim, 2005: 7-8)

Surah Mudatstsir (74): 1-5) artinya: "Hai orang yang berselimut, bangunlah, lalu berilah peringatan! Dan Rabbmu agungkanlah! Dan pakaianmu bersihkan lah! Dan perbuatan dosa tinggalkanlah". Ayat-ayat ini merupakan pemberitahuan kepada Nabi untuk melakukan pekerjaan besar. Ayat-ayat ini merupakan perintah pertama untuk menyampaikan dakwah.

Setelah turun ayat permulaan surah Al-Mudatstsir, Rasulullah mulai berseru mengajak menyembah kepada Allah dan mengajak untuk masuk Islam secara sembunyi-sembunyi. Beliau mulai mengajak keluarga, shahabat, serta orangorang dekat beliau (Ash-Shalabi, 2014: 105).

Orang yang pertama kali beriman kepada Nabi saw dari kalangan perempuan atau bahkan orang yang pertama kali beriman kepada beliau secara mutlak adalah Sayyidah Khadijah ra. ia adalah orang yang pertama kali mendengarkan wahyu dari lisan Rasulullah, dan orang yang pertama kali membaca al-Quran setelah ia mendengarnya dari Rasulullah (Ash-Shalabi, 2014: 106).

Setelah sayyidah Khadijah beriman, Ali bin Abu Thalib pun masuk Islam. Ia adalah orang yang pertama kali masuk Islam dari kalangan anak kecil. Ketika itu ia berusia sepuluh tahun. Kemudian islamnya Zaid bin Haritsah AlKalbi, ia adalah orang yang pertama kali beriman dengan dakwah Nabi saw dari kalangan budak sekaligus anak angkat Rasulullah. Demikian juga semua anak-anak Nabi saw segera masuk Islam yaitu Zainab, Ummu Kultsum, Fathimah, dan Ruqayyah. Mereka semua telah terkesan dengan oleh ayah mereka sebelum diutus menjadi Nabi, dengan keistiqamahannya, kebaikan perjalanan hidupnya, dan kebersihan dirnya dari apa yang dilakukan oleh orang-orang jahiliyah. Dengan demikian rumah Nabi saw menjadi keluarga pertama yang beriman kepada Allah saw yang tunduk kepada syariat-Nya dalam Islam. Rumah Nabi memiliki kedudukan utama dalam sejarah dakwah Islam (Ash-Shalabi, 2014: 106-107). 
Abu Bakar ash-Shiddiq adalah orang pertama yang beriman kepada Nabi dari kalangan laki-laki yang merdeka dan terpandang. Ia adalah shahabat Nabi, yang paling utama sebelum beliau diutus. Rasulullah SAW bersabda: "Tidaklah aku mengajak seseorang untuk masuk Islam melainkan ia memiliki kebimbangan serta keraguan, dan memikirkan dahulu, kecuali Abu Bakar, ia tidak diam menunggu ketiak aku mengajaknnya dan tidak pula ragu-ragu.". Keislaman Abu Bakar bukan hanya Islamnya satu orang, melainkan Islamnya satu umat. Karrena itu ketika ia bergerak dalam dakwahya untuk Islam maka dengan mudah diterima oleh orang-orang pilihan dari kalangan orang-orang terbaik, mereka adalah Utasman bin Affan, Abdurrahman bin 'Auf, Sa'ad bin Abi Waqqash, Az-Zubair bin Al-Awwam, Thalhah bin 'Ubaidillah. (Ash-Shalabi, 2014: 108-109).

Nabi melanjutkan dakwahnya dengan sembunyi-sembunyi, mengajak sejumlah pengikut dan pendukung dari kalangan kerabatnya dan teman-temannya, khususnya orang-orang yang dapat turut serta secara sembunyi-sembunyi, setelah mereka memeluk Islam. Inilah tahap yang sulit dari kehidupan dakwah Rasulullah yang muncul di dalamnya kesukaran dan kesusahan dalam pergerakan dakwah Rasulullah dan orang yang berikan kepada beliau. Mereka tidak mengajak berbicara kecuali kepada orang yang aman dari kejahatannya, dan mempercayainya (AshShalabi, 2014: 112). Dakwah dengan sembunyi-sembunyi ini merupakan dakwah tahap pertama.

Rasulullah dalam menyebarkan agama Islam dilakukan secara bertahap, yang dapat dibagi menjadi dua periode, yaitu; periode Mekkah yang berjalan kira-kira tiga belas tahun dan periode Madinah, berjalan selama sepuluh tahun penuh.

Setiap periode miliki tahapan-tahapan tersendiri, dengan kekhususan kondisi masyarakat masing-masing, yang satu berbeda dengan yang lain. Pada periode Mekkah dapat dibagi menjadi tiga tahapan, yaitu: 1) tahapan dakwah secara sembunyi-sembunyi, yang berjalan selama tiga tahun, hal ini dilakukan agar penduduk Mekkah yang menyembah berhala tidak kaget karena tiba-tiba menghadapi sesuatu yang berbeda dengan kebiasaan mereka. Dakwah dilakukan kepada keluarga yang paling dekat dan dikenal baik oleh Rasulullah, 2) tahapan dakwah secara terang-terangan di tengah penduduk Mekkah, yang dimulai sejak tahun keempat dari nubuwah hingga akhir tahun kesepuluh, 3) tahapan dakwah di luar Mekkah dan penyebarannya, yang dimulai dari tahun kesepuluh dari nubuwah hingga hijrah ke Madinah (Al-Mubarrakfury, 2003: 101).

Demikian juga pada pada periode Madinah bisa dibagi menjadi tiga tahapan masa, yaitu; 1) tahapan masa yang banyak diwarnai guncangan dan cobaan, banyak rintangan yang muncul dari dalam, sementara musuh dari luar menyerang Madinah untuk menyingkirkan para pendatangnya. Tahapan ini berakhir dengan dikukuhkannya perjanjian Hudaibiyah pada bulan Dzul-Qa'idah tahun ke-6 Hijriah, 2) tahapan masa perdamaian dengan para pemimpin paganisme, yang berakhir dengan Fathu Mekkah pada bulan Ramadhan tahun ke-8 Hijriah. Ini juga merupakan tahapn masa berdakwah kepada para raja agar masuk Islam, dan 3) tahapan masa masuknya manusia ke dalam Islam secara berbondong-bondong, yaitu masa kedatangan para utusan dari berbagai kafilah dan kaum ke Madiah. Masa ini membentang hingga wafatnya Rasulullah pada bulan Rabi'ul Awwal tahun ke-11 Hijriah. (Al-Mubarrakfury, 2003: 237).

Rasulullah melaksanakan dakwah Islam selama kurang lebih 13 tahun pada periode Makkah dan sekitar 10 tahun pada periode Madinah. Karena itu, banyak 
anggapan yang menyatakan total dakwah Nabi selama lebih kurang 23 tahun, padahal tepatnya adalah 22 tahun 2 bulan, dan 22 hari (Badri Yatim, 2005: 7).

Secara khusus Iwan (2008, http://bdkjakarta.kemenag.go.id/index.php?a= artikel\&id=852) menguraikan tahapan dakwah Nabi saw yang selama kurang lebih tiga belas tahun itu pada periode Makkah dalam tiga tahap, yaitu: Tahap pertama, dakwah secara diam-diam selama sekitar tiga tahun. Dasarnya adalah surat AlMudatstsir ayat $1-7$. Dalam tahap ini Rasululllah mengajak keluarga yang tinggal serumah dan para sahabat terdekatnya agar meninggalkan paganisme, dan beribadah hanya kepada Allah semata. Pada fase ini yang pertama menyatakan beriman dan menerima risalah Islam adalah istrinya sendiri yaitu Khadijah, saudara sepupunya yakni Ali bin Abi Tahlib dan budak yang sudah dimerdekakan yaitu Zaid bin Haritsah. Dari kalangan sahabat, yaitu Abu Bakar. Dan dengan perantaraan Abu Bakar turut pula Utsman bin Affan, Zubair bin Awam, Saab bin Abi Waqash, Thalhah bin Ubaidillah, Abd. Rahman bin Auf, Abu Ubaidah bin Jarrah, Arqam bin Abi al-Arqam, Bilal bin Rabbah dan beberapa penduduk Makkah lainnya, seperti Fatimah binti Khatthab (adik Umar ibn Khattab) bersama suaminya Said bin Zaid al-'Adawi. Rasulullah mengajarkan Islam kepada mereka di rumah Arqam bin Abi al-Arqam. Mereka yang pertama-tama beriman ini kemudian disebut assabiqunal awwalun. Generasi pertama pengikut Nabi ini aktif pula mengajak sanak saudara mereka masing-masing yang belum beriman. Terutama keluarga yang mereka yakini dapat memegang rahasia.

Tahap kedua, dakwah semi terbuka. Dalam tahap ini Rasulullah menyeru keluarganya dalam lingkup yang lebih luas (kepada Bani Hasyim) berdasarkan Q.S.Asy-Syua'ara ayat 214 yang artinya "Dan berilah peringatan kepada kerabatkerabatmu yang terdekat". Yang menjadi sasaran utama seruan ini adalah Bani Hasyim. Setelah itu Rasulullah memperluas jangkauan seruannya kepada seluruh penduduk Makkah.

Tahap ketiga, dakwah terang-terangan. Dakwah terang-terangan ini ditandai dengan turunnya Q.S. Al-Hijr; 15 ayat 94, yang artinya Maka sampaikanlah olehmu secara terang-terangan segala apa yang diperintahkan (kepadamu) dan berpalinglah dari orang-orang yang musyrik.cAyat ini merupakan perintah dakwah secara terbuka (terang-terangan) kepada penduduk Makkah. Sejak saat itu Islam mulai menjadi perhatian dan pembicaraan penduduk Makkah. Rasulullah terus meningkatkan dan memperluas jangkauan kegiatan dakwahnya, tidak lagi terbatas pada keluarga dan penduduk Makkah, melainkan kepada setap orang yang datang berziarah ke Ka'bah di kota Makkah terutama pada musim haji.

Melalui petunjuk dan hidayah Allah SWT tersebut. Rasulullah mulai menata dan mengatur aktivitas dakwahnya. Secara hirarkis, tugas utama beliau adalah sebagai nabi, kemudian sebagai pengingat keluarga dekatnya, pengingat kaumnya, pengingat bangsa Arab dan yang terakhir beliau adalah pengingat seluruh manusia untuk kerja dakwah beliau sampai akhir zaman. Sejak itu mulailah kaum muslimin berkumpul bersama Rasulullah SAW di rumah Arqam ibnu Abi Arqam untuk belajar al-Quran dan mempelajari petunjuk Islam. Sementara Rasululah membimbing mereka dengan pendidikan yang benar dan membersihkan diri mereka.

Setelah tiga tahun dakwah berjalan secara rahasia dan bersifat individual, dengan metode dakwah yang dipakai adalah metode dialog (hiwar) dengan bersandarkan pada interaksi personal (Thoifah, 2015: 58). Dilihat dari sudut metode dakwah, dengan dimulainya dakwah terang-terangan, maka berubahlah metode yang dipakai, yang awalnya berupa dialog dan komunikasi interpersonal, saat itu 
ditambah dengan metode khitabah (ceramah) dan presentasi umum dihadapan masyarakat. Adapun cara dakwahnya dengan menggunakan pendekatan targhib dan tarhib (upaya persuasive dengan menarik minat kepada hal yang baik dengan pahala dan menakuti terhadap hal yang tidak baik dengan azab).(Ibrahim alJayusyiy, 1999 dalam Thoifah, 2015: 59)

Proses dakwah Islam, jika dilihat dari segi konteks atau levelnya, merupakan proses interaksi antara da'i dengan mad'u baik secara kuantitatif maupun kualitatif, maka prosesnya terbagi pda enam macam konteks, yaitu: (1) dakwah nafsiyah, yaitu proses interaksi antara da'i dengan diri sendiri sebagai mad'u-nya; (2) dakwah fardhiyah, yaitu proses dakwah seorang da'i terhadap seorang mad'u dalam suasana dialogis dan kontak langsung; (3) dakwah fi'ah, yaitu proses dakwah seorang da'i terhadap sekelompok mad'u secara tatap muka, dan dialogis yang berlangsung dalam bentuk kelompok kecil, dan kelompok-kelompok mad'u yang sudah terorganisir, misalnya majelis taklim, madrasah dan ma'had (pesantren): (4) dakwah hizbiyah, yaitu jam'iyah, yaitu proses dakwah yang dilakukan oleh da'I yang mengidentifikasikan dirinya dengan atribut suatu lembaga atau organisasi dakwah tertentu, kemudian mendakwahi anggotanya atau orang lain di luar anggota suatu organisasi tersebut; (5) dakwah ummah, yaitu seorang da'I mendakwahi orang banyak melalui media mimbar atau media massa baik cetak atau elektronik dalam suasana monologis, dalam suasana bertatap muka atau tidak bertatap muka; dan (6) dakwah syu'ubiyah qabailiyah, seorang da'i yang beridentitas etnis dan budaya atau bangsa yang berbeda dengan dirinya (Enjang \& Aliyuddin, 2009: 51)

Berdasarkan konteks sejarah dakwah Rasulullah SAW tersebut, maka komunikasi interpersonal menjadi strategi dakwah Rasulullah yang sangat penting, terutama pada periode Mekkah, pada tahap pertama sekali menyebarkan Islam secara sembunyi-sembunyi, yang dimulai dari keluarga terdekat. Dakwah pada saat itu dilakukan dalam konteks dakwah fardhiyah dimana seorang da'i melaksanakan dakwah kepada seorang mad'u dalam suasana dialogis dan kontak langsung. Seorang da'i yang melakukan dakwah secara fardhiyah berarti telah melakukan komunikasi interpersonal.

\section{Tinjauan Psikologi tentang Komunikasi Interpersonal sebagai Strategi Dakwah Rasulullah}

Turunnya wahyu adalah suatu hal yang berat bagi Rasululllah saw. Meskipun beliau adalah orang yang paling gagah berani dan paling kuat hatinya, tapi tetap merupakan hal yang berat. Hal itu disebabkan interaksi tersebut bukan hanya perbincangan biasa antara seseorang dengan orang lain. Akan tetapi, interaksi tersebut adalah perbincangan malaikat agung yang membawa firman Allah swt agar diterima oleh orang yang telah dipilih oleh-Nya untuk membawa dan menyampaikannya kepada seluruh umat manusia. Tentunya itu adalah tanggung jawab yang besar. Tidak ada yang kuat, selain orang yang dipilih oleh Allah untuk membawa risalah itu dan menyampaikannya. (Ash-Shalabi, 2014: 98).

Setelah menerima wahyu Rasulullah merasa takut dan memerlukan seseorang yang dapat diajak berbicara dan dapat dipercaya. Dalam konteks sejarah Siti Khadijah adalah orang pertama yang mendengarkan berita turunnya wahyu kepada Rasulullah. Ash-Shalabi (2014: 94) mengemukakan bahwa Nabi SAW telah ditimpa rasa takut dari apa yang beliau dengar dan lihat. Beliau lalu bergegas menuju rumahnya utuk menenangkan diri. 
Sikap Khadijah menunjukkan kekuatan hatinya. Ia tidak merasa takut ketika mendengar kabar dari Nabi saw dan ia menghadapi perkara itu dengan tenang. Hal ini terbukti dari tindakannya setelah kejadian tersebut dengan pergi menemui Waraqah bin Naufal dan menjelaskan perkara itu kepadanya. Tindakan Khadijah tersebut menunjukkan eluasan pengetahuannya. Ia membandingkan antara yang ia dengar dan apa yang dialami Nabi saw, sehingga ia mengetahui bahwa orang yang diberi kemuliaan akhlak itu tidak akan dihinakan Allah selamanya. Ia telah mensyifati bahwa beliau selalu menyambung silaturahmi, dan seseorang yang menyambung kekerabatan merupakan penanda terhadap kesiapan dirinya untuk memberikan kebaikan dan berbuat baik kepada orang banyak sebab, keadaan para kerabat adalah cermin utama dari akhlak seseoarang. Jika ia berhasil menghimpun kerabatnya dan mengupayakan mereka dengan kebaikan, biasanya ia juga berhasil dalam mengusahan orang lain selain mereka. (Ash-Shalabi, 2014: 98).

Ummul mukminin Khadijah ra. telah bergegas kepada fitrah imannya dan kepada pengetahuannya tentang sunnah-sunnah Allah dalam makhluk-Nya. Ia juga merasa yakin dengan apa yang dimiliki Muhammad saw, berupa akhlak dan segala sifat utamanya yang tidak dimiliki oleh seorang pun selain beliau dalam interaksi kesehariannya terhadap masyarakat sekitar. Ia yakin bahwa suaminya memiliki tabiat sempurna. Dialah insan paling sempurna yang menjamin kemenangan, serta mewujudkan keberhasilan dan kesuksesan baginya. Dari sini dapat terlihat betapa jelas ia mengungkapkan kesempurnaan sosok Muhammad. (Ash-Shalabi, 2014: 98).

Khadijah telah melakukan peran penting dalam kehidupan Nabi, karena ia memiliki kepribadian terpuji di tengah kaumnya, ia juga senantiasa memberi dukungan moral kepada beliau yang berupa akhlak yang luhur, seperti kasih sayang, murah hati, bijaksana, keteguhan hati, dan akhlak mulia lainnya. Rasul pun telah diberi taufik oleh Allah kepada isteri yang dapat menjadi teladan ini. Seebab, beliau adalah teladan bagi semua orang, terutama bagi para da'I yang mengajak kepada Allah. Maka apa yang dilakukan dan semua peranan Khadijah itu adalah bentuk pemberitahuan dari Allah set agi semua pengemban dakwah Islam agar mereka dapat menempuhnya dengan meneladani Rasulullah hingga terwujudnya tujuan luhur yang mereka usahakan. (Ash-Shalabi, 2014: 100).

Perbincangan Nabi Muhammad dengan Siti Khadijah merupakan bentuk komunikasi interpersonal yang sangat efektif. Keduanya melakukan peran komunikator dan komunikan dengan baik, saling support, terbuka, dan saling percaya. Di sini Isteri yang shalehah memiliki peran dalam keberhasilan dakwah. Hal ini telah tampak jelas dalam peran Khadijah dan apa yang telah ia lakukan. Ia mendampingi Rasulullah dalam menjalankan tugas berat, mengemban tugas menyampaikan risalah kepada umat manusia.

Secara psikologis komunikasi interpersonal akan berjalan dengan baik jika kedua belah pihak yang berkomunikasi itu telah mengenal satu sama lain, saling memberikan perhatian, dukungan, keterbukaan dan kepercayaan. Bahkan suatu komunikasi akan dikatakan sebagai komunikasi interpersonal jika komunikasi yang dilakukan sudah sampai pada tahap psikologis. Miller dan Steinberg (dalam Budyatna \& Nina Mutmainah, 1994: 12) menyebutkan ada tiga tingkatan dalam melakukan predisi dalam komunikasi, yaitu tingkat kultural, tingkat sosiologis dan tingkat psikologis. Dalam berkomunikasi pada tingkat kultural, komunikator melakukan prediksi berdasarkan data kultural yang dianut oleh pelaku komunikasi lainnya. Pada tingkat sosiologis, komunikator melakukan prediksinya berdasarkan data-data sosiologis pihak lain yang diajaknya berkomunikasi, yaitu berupa nilai 
dan norma kelompok yang dianut pihak lain tersebut, adapun prediksi pada tingkat psikologis didasarkan pada data psikologis pihak lain yang berkomunikasi, yakni karakteristik khas dan kepribadian pihak lain. Sehingga semakin besar pada pelaku komunikasi saling mengenal secara individu satu sama lain, maka komunikasi makin bersifat personal/pribadi. Sebaliknya makin kecil tingkat pengetahuan individu satu sama lain, maka komunikasi menjadi makin impersonal.

Komunikasi interpersonal yang dilakukan oleh Rasulullah pada periode pertama merupakan komunikasi tingkat psikologis. Orang-orang pertama yang diajak beliau adalah orang-orang yang paling terdekat di lingkungan keluarga dan juga sahabat. Hubungan yang dekat dengan keluarga dan sahabat akan menentukan kualitas komunikasi interpersonal Secara psikologis, hubungan interpersonal komunikator dan komunikan membuat keduanya merasa dekat, saling percaya, saling terbuka, saling mendukung, perhatian, merasa nyaman, dan aman dalam berkomunikasi.

Lebih lanjut dengan melihat sejarah perkembangan dakwah Rasulullah tampak jelas bahwa beliau dalam berdakwah sangat memperhatikan kondisi psikologis masyarakat penerima dakwah, sehingga pelaksanaan dakwah terbagi menjadi beberapa tahap. Komunikasi interpersonal sebagai strategi dakwah lebih sering digunakan Rasulullah pada periode mekkah, terutama ketika dakwah dilakukan dengan sembunyi-sembunyi. Sementara dakwah berikutnya strategi yang digunakan lebih bervariasi dengan tidak meninggalkan komunikasi interpersonal. Komunikasi interpersonal yang dilakukan Rasulullah menyesuaikan dengan kebutuhan dakwah.

Terkait dengan teks tersebut, William C. Schutz (1958 dalam Ramaraju: 2012: 71) memahami komunikasi interpersonal yang didasarkan pada kebutuhan interpersonal. Menurut Schutz, kebutuhan interpersonal dapat terbagi dalam tiga kategori, yaitu: inclusion, control dan affection. Inclusion berkenaan dengan kebutuhan untuk memelihara hubungan yang memuaskan dengan orang lain dan untuk menunjukkan kepemilikan dan keterlibatan yang cukup. Control diasosiasikan dengan kebutuhan untuk pengaruh dan kekuasaan. Affection berkenaan dengan kebutuhan pertemanan, kedekatan dan cinta. Setiap kebutuhan interpersonal seseorang berbeda-beda. Kesadaran individu akan kebutuhan interpersonal memungkinkan seseorang memahami lebih baik tingkah laku komunikasi. System Schutz mengusulkan bahwa pertemuan interpersonal yang sukses adalah dimana kebutuhan-kebutuhan interpersonal dari pesertanya terpuaskan.

Memperluas gagasan Schutz, Abraham Maslow mengusulkan bahwa kita berkomunikasi untuk memenuhi berbagai kebutuhan manusia. Menurut Maslow, kebutuhan dasar harus dipenuhi.

1. Kebutuhan fisik. Pada tingkat yang paling dasar, manusia perlu untuk bertahan hidup, dan komunikasi membantu kita memenuhi kebutuhan ini.

2. Kebutuhan Keselamatan. Untuk memenuhi keselamatan perlu melalui komunikasi.

3. Kebutuhan Kepemilikan. Kita berkomunikasi untuk memenuhi milik kebutuhan dengan berbicara dengan orang lain, mendengarkan dan menanggapi apa yang mereka katakan, berbagi pikiran dan perasaan

4. Kebutuhan harga diri. Komunikasi merupakan cara utama kita menggambarkan/mencari tahu siapa kita dan apa yang kita bisa. Kita mendapatkan pengertian pertama tentng diri kita dari orang lain yang 
berkomunikasi bagaimana mereka melihat kita. Proses ini berlanjut sepanjang kehidupan seperti yang kita melihat diri kita tercermin dalam mata orang lain

5. Kebutuhan aktualisasi diri. Menurut Maslow, kebutuhan manusia yang paling abstrak adalah aktualisasi diri.Sebagai manusia, kita mencari lebih dari kelangsungan hidup, keselamatan, milik, dan harga diri. Komunikasi mendorong pertumbuhan pribadi kita. Untuk ini, kita mengandalkan komunikasi (Wood, J.T. 2010: 11-13).

Komunikasi yang dikembangkan oleh Maslow ini tampak berbeda dengan komunikasi interpersonal dalam konteks dakwah Rasulullah. Rasulullah melakukan komunikasi interpersonal dalam melaksanakan dakwah bukan untuk memenuhi kebutuhan pribadi (kebutuhan, fisik, keselamatan, kepemilikan, harga diri dan aktualisasi diri), sebaliknya komunikasi interpersonal yang dikembangkan Rasulullah adalah lebih mengutamakan kondisi dan kebutuhan komunikannya (mad,u) dan semata-mata melaksanakan misi yang diembankan Allah SWT. Komunikasi interpersonal secara sembunyi-sembunyi yang dilakukan Rasulullah disesuaikan dengan kondisi dan budaya masyarakat Arab yang belum siap menerima ajaran tauhid, sekaligus mengikuti tuntunan Allah sampai diperintahkan berdakwah secara terang-terangan. Apa yang dilakukan Rasulullah menunjukan bahwa beliau memiliki kompetensi komunikasi yang unggul.

Kompetensi komunikasi seseorang dapat dilihat dari lima dimensi, yaitu: (1) afiliasi (persatuan)/ support (dukungan), (2) social relaxation, (3) empati, (4) behavioral flexibility, dan (5) keterampilan manajemen interaksi (Rickheit, G. dan Strohner, H. 2008: 19). Dalam berkomunikasi interpersonal, pesan yang disampaikan Rasulullah telah berhasil mengajak orang didekatnya mendukung baik moril maupun material, dan meningkatkan rasa empati dan hormat. Perilaku Rasulullah yang mulia, jujur, ramah, lembut, santun, terpercaya, amanah dan berani menyampaikan yang benar telah mengantarkan pada keberhasilan komunikasi interpersonal.

Rasulullah sebagai komunikator telah menciptakan proses komunikasi menjadi efektif dengan memperhatikan kesiapan fisik dan mental, materi yang akan disampaikan, corak komunikasi, situasi dan kondisi tempat dakwah dilaksanakan. Semua itu dilakukan agar pesan yang disampaikan sesuai dengan kebutuhan, situasi dan kondisi mad'u, sehingga pesan dapat diterima dan dakwah dapat berjalan secara afektif dan efisien.

\section{Penutup}

Paparan di atas dapat disimpulkan bahwa komunikasi interpersonal merupakan strategi dakwah yang penting. Para da'i dapat menggunakan strategi ini dalam berdakwah, sebagaimana dakwah yang dilakukan oleh Rasulullah SAW. Kemampuan da'i dalam berkomunikasi interpersonal sangat mendukung kegiatan dakwah. Belajar dari sejarah dakwah Rasulullah, komunikasi interpersonal menjadi bagian yang sangat penting dalam keberhasilan dakwah Rasulullah. Berdasarkan perspektif psikologi, komunikasi interpersonal akan berjalan lancar jika komunikator dan komunikan melakukan komunikasi pada tingkat psikologis, 
dimana kedua belah pihak saling kenal, merasa dekat, nyaman, saling mendukung dan percaya satu sama lain. Itulah komunikasi interpersonal yang dilakukan Rasulullah pada tahap pertama periode Mekkah. Dakwah dan ajaran Islam yang disampaikan Rasulullah secara bertahap juga menunjukkan bahwa Rasulullah sangat memperhatikan aspek psikologis masyarakat Arab. Penggunaan komunikasi interpersonal yang tepat sesuai dengan konteks dakwah akan membawa kesuksesan dakwah Islamiyah.

\section{Referensi}

Al-Mubarrakfury, Shafiyyur Rahman. 2003. Sirah Nabawiyah, Alih Bahasa oleh Kathur Suhardi, Jakarta: Pustaka Al-Kautsar.

Ash-Shallabi, Ali Muhammad, 2014. Sirah Nabawiyyah, Surakarta: Insan Kamil

Aziz, Moch Ali, 2009, Ilmu Dakwah, Jakarta: Kencana Prenada Media Group

Badri Yatim, Dari Makkah ke Madinah, dalam Ensiklopedi Tematis Dunia Islam, Jilid 2, Tema Khilafah, Jakarta, PT. Ichtiar Baru Van Hoeve, 2005.

Budyatna \& Nina Mutmainah, 1994, Komunikasi antar Pribadi, Jakarta: Universitas Terbuka

Cangara, Hafied, 2012. Pengantar Imu Komunikasi, Jakarta: Raja Grafindo Persada

Effendy, Onong U., 2004. Dinamika Komunikasi, Bandung: Remaja Rosdakarya

Effendy, Onong U., 2011. Komunikasi: Teori dan Praktek, Bandung: Remaja Rosdakarya.

Enjang dan Alyudin. 2009. Dasar-dasar Ilmu Dakwah: Pendekatan Filosofis dan Praktis, Bandung: Widya Padjadjaran.

Falahuddin, Iwan, 2008. Sejarah Nabi Muhammad Saw Pada Periode Makkah, Pengayaan Materi Mata Diklat Sejarah Kebudayaan Islam Bagi Guru Madrasah Tsanawiyah), Jakarta: Balai Diklat Kementerian Agama Republik Indonesia, http:/ / bdkjakarta.kemenag.go.id/index.php?a=artikel\&id=852

Knapp, Mark L. \& Daly, John A., 2002. Handbook of Interpersonal Communication, Cambridge Universitu Press, New York.

Mulyana, Deddy, 2013, Imu Komunikasi: Suatu Pengantar, Bandung: Remaja Rosdakarya

Ramaraju, S., 2012, Psychological Persperctives on Interpersonal Communication, Journal of Arts, Science \& Commerce, Vol. III, 4 (2): 68-73

Rickheit, G \& Strohner (ed.), H. 2008. Handbook of Communication competence, Walter de Gruyter GmbH \& Co. KG., Berlin.

Solomon D. \& Theiss J. 2013. Interpersonal Communication: putting theory intro practice. New York: Routledge Taylor \& Francis Group

Thoifah, I'anatut, 2015. Manajemen Dakwah: Sejarah dan Konsep, Malang: Madani Press

Wood, Julia T., 2010. Interpersonal Communication, edition 6, Boston: Wadsworth Cengage Learning 